\title{
Prediction of the environmental impact and sustainability of large-scale irrigation with gypsiferous mine-water on groundwater resources
}

\author{
JG Annandale ${ }^{\text {1*}}$, NZ Jovanovic ${ }^{1}$, FDI Hodgson², BH Usher², ME Aken ${ }^{3}$, AM van der Westhuizen', \\ KL Bristow ${ }^{4}$ and JM Steyn ${ }^{1}$ \\ ${ }^{1}$ Dept. Plant Production and Soil Science, University of Pretoria, 0001, Pretoria, South Africa \\ ${ }^{2}$ Institute for Groundwater Studies, University of the Free State, Bloemfontein 9300, South Africa \\ ${ }^{3}$ Anglo Coal Environmental Services, Private Bag X9, Leraatsfontein, 1038, South Africa \\ ${ }^{4}$ CSIRO Land and Water, PMB Aitkenvale, Townsville, QId 4814, Australia
}

\begin{abstract}
Irrigation of agricultural crops is one of the most cost-effective options for the utilisation of gypsiferous mine wastewater. In addition, it creates the opportunity to produce crops during the dry season. Gypsum is a slightly soluble salt and concentrating the gypsiferous soil solution through crop evapotranspiration precipitates gypsum in the soil profile, removing it from the water system and reducing the potential for groundwater pollution. In previous research, it was found that crops can be commercially produced under irrigation with gypsiferous mine-water with no obvious impact on groundwater in the short term (3 years). It was, however, recommended that monitoring should continue to confirm findings over a longer period and for different conditions. A research project was therefore initiated in 2001 to determine the impact of irrigation with several gypsiferous water/soil combinations on crop performance, soil properties and groundwater quality. Field trials were carried out in South Africa on three mines: Kleinkopjé and New Vaal Collieries (Anglo Coal), and at Syferfontein (Sasol). Different crop and pasture species were grown on different soil types under centre-pivot irrigation with different mine-water qualities.

Intensive monitoring systems were established in each irrigated field to determine the components of the soil-water and salt balance. Boreholes were also installed to monitor groundwater level and quality. Field water and salt balance data were used for calibration and validation of the mechanistic, generic crop, Soil-Water Balance (SWB) Model. The results of the field trials indicated that high crop and pasture yields can be obtained, provided site selection, land preparation, fertilisation and irrigation water management are appropriate. The results of the soil-water and salt balance studies indicated that considerable volumes of mine-water can be used and substantial amounts of salts can be removed from the water system through precipitation of gypsum in the soil profile. The groundwater impact was limited based on borehole measurements, indicating the presence of a zone of attenuation between the cropped soil profile and groundwater, but this should be monitored over a longer period. With appropriate management, water and salt runoff, and under specific conditions, drainage and salts leached can be intercepted, thereby minimising unwanted impacts on groundwater. Thirty-year scenario simulations were run with SWB and the generated salt loads from this model were used as input into a separate groundwater model in order to predict the likely long-term effects of irrigation with gypsiferous mine-water on groundwater. The results of these simulations showed that while salts reached the groundwater, there was a drop in concentration of the plume as it moved away from the irrigated area. This was due largely to dilution by infiltration from rainfall recharge and the dispersive characteristics of the aquifer. The simulations also showed the importance of matching the amount of drainage from an irrigated site with the transmissivity and storage properties of the aquifer below. These results suggest that large-scale irrigation with gypsiferous water could be viable if irrigated fields are carefully sited to prevent waterlogging and are well managed. A site-specific approach is essential.
\end{abstract}

Keywords: irrigation, gypsiferous, mine-water, groundwater, simulations, SWB

\section{Introduction}

Mining in South Africa generates large volumes of mine wastewater that have the potential to adversely affect an already scarce water resource if not properly managed (Tanner et al., 1999). Disposal of mine wastewater is a world-wide problem, occurring wherever operating mines, as well as closed underground and open-cast workings, are found (Pulles et al., 1995). The type of wastewater emanating from mines depends

* To whom all correspondence should be addressed.

诲 +2712420 3223; fax: +27124204120 ;

e-mail: john.annandale@up.ac.za

Received 10 March 2004; accepted in revised form 14 November 2005. largely on the chemical properties of the geological materials that come into contact with the water (Thompson, 1980). The concentrations of salts and other constituents frequently render such waters unsuitable for direct discharge to the river systems, except in periods of high rainfall when adequate dilution capacity is present, and controlled release is permitted by the regulatory authorities (Pulles et al., 1996). In many cases the mine effluent is gypsiferous, meaning that it is dominated by calcium and sulphate ions. This occurs when acid mine drainage (AMD) is neutralised by naturally occurring calcite or dolomite, or by active liming, which may be required to correct $\mathrm{pH}$ and precipitate out metals (Van Staden, 1979).

The potential of gypsiferous mine-water for use in crop irrigation was first evaluated in South Africa by Du Plessis (1983), using a steady-state chemical equilibrium model (Oster and 


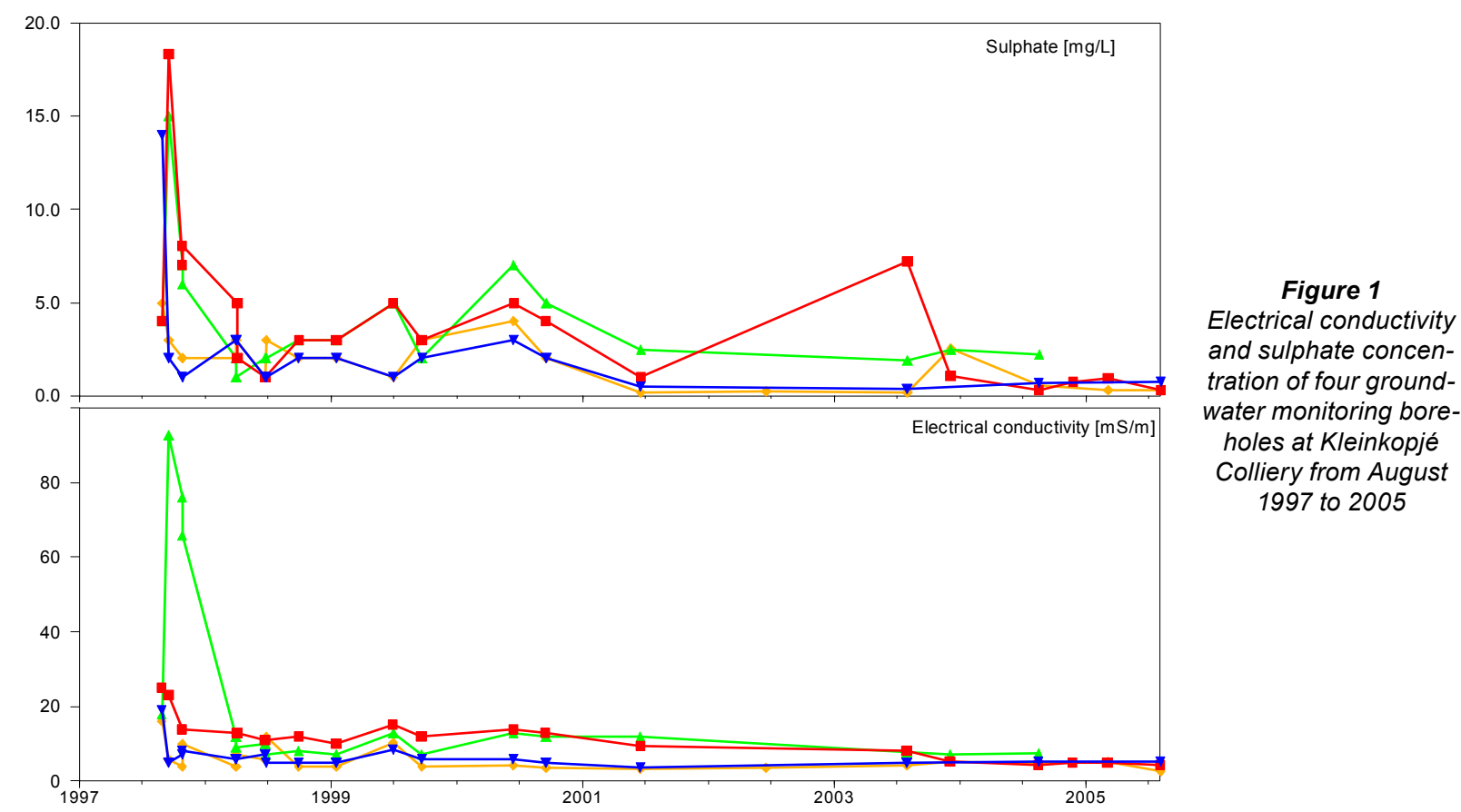

Rhoades, 1975) to predict the amount of salt that leached, and could potentially contaminate groundwater. Simulation results indicated that irrigating with gypsum rich water would result in lower soil- and percolate salinity compared to a chloride rich water of otherwise similar ionic composition. This could be attributed to precipitation of gypsum in the soil. The increased sodium hazard caused by gypsum precipitation was not expected to seriously affect soil physical properties and crop yield using a typical mine-water quality for irrigation (Du Plessis, 1983).

The use of gypsiferous mine wastewater for irrigating agricultural crops presents an opportunity to stabilise dry-land crop production and enable dry season production, whilst at the same time providing a cost-effective method for minimising excess mine drainage (Jovanovic et al., 2002). By irrigating with gypsiferous wastewater, a large fraction of the salts can be removed from the water system through precipitation of gypsum in the soil profile, as the soil solution is concentrated by root water uptake. This reduces the likelihood of off-site environmental pollution. Comparisons of the capital costs of irrigation as minewater management option, to those of several treatment options, show irrigation to be lower by an order of magnitude. Running costs are not only covered by the income generated from the sale of produce, but profits can be made and jobs created, which is particularly important in the post-closure period.

Reasonable estimates of volumes of mine-water stored and generated are available for a number of active mines in the central Witbank coalfields (Mpumalanga Province, South Africa). Grobbelaar et al., (2004) indicate that $360 \mathrm{M} \ell \cdot \mathrm{d}^{-1}$ may be generated after closure in the entire Mpumalanga coalfields. For the Olifants catchment, a volume of $170 \mathrm{Ml} \cdot \mathrm{d}^{-1}$ is suggested. Not all this water will report to the same locality, and several sub-areas where water will decant from the mines are envisaged. The expected discharge at each decanting position ranges between 12 and $40 \mathrm{M} \ell \cdot \mathrm{d}^{-1}$. These volumes of decant water have the potential to support in excess of 6000 ha of irrigation in the Olifants catchment alone. On a site-specific scale, for instance, Kleinkopje Colliery (Witbank, Mpumalanga) currently has some $12 \times 10^{6} \mathrm{~m}^{3}$ of water stored underground, and it is estimated from pumping and water level data that the daily water make is in the order of $14 \mathrm{M} \ell \cdot \mathrm{d}^{-1}$ (Grobbelaar et al., 2004). This is sufficient to sustain an irrigated system of some 500 to $700 \mathrm{ha}$, depending on the particular cropping system chosen (Jovanovic et al., 2002).

The use of gypsiferous mine-water from South African collieries for irrigation has been investigated in quite some detail in South Africa. A wide range of crop and pasture species were screened for tolerance to irrigation with limetreated AMD at Landau Colliery (Anglo Coal, Witbank, Mpumalanga Province) from 1993 to 1996 (Barnard et al., 1998; Jovanovic et al., 1998). Higher crop yields were obtained under irrigation with mine-water compared to dry-land production, without any foliar injury to the crop. Possible nutritional problems, for example deficiencies in $\mathrm{K}, \mathrm{Mg}$ and $\mathrm{NO}_{3}$, occurring due to $\mathrm{Ca}$ and $\mathrm{SO}_{4}$ dominating the system, can be solved through fertilisation. Soil salinity increased compared to the beginning of the trial, but the values of soil saturated electrical conductivity stabilised at a relatively low level around $200 \mathrm{mS} \cdot \mathrm{m}^{-1}$, which is typical for a saturated gypsum solution. The commercial production of several centre pivot irrigated crops with gypsiferous mine-water has also been tested in field trials at Kleinkopje Colliery (Anglo Coal, Witbank, Mpumalanga Province) since 1997 (Annandale et al., 2001; Jovanovic et al., 1998), and by Beletse (2004) at Syferfontein (SASOL, Secunda, Mpumalanga Province) and New Vaal Colliery (Anglo Coal, Vereeniging, Free State Province) since 2001.

Data collected have been used to validate SWB (Annandale et al., 1999a), a mechanistic soil water balance model which has been used for long-term predictions of the likely impact of irrigation with gypsiferous mine-water on soil and groundwater resources. Crops like sugar-beans, wheat, maize, potatoes and pastures were very successfully produced under irrigation with gypsiferous mine-water. Land preparation and fertilisation management are critical for successful crop production, especially on rehabilitated soil. In the short to medium term (eight years) irrigation with gypsiferous mine-water proved to be sustainable with a negligible impact on groundwater. This is depicted in Fig. 1 for several monitoring boreholes in and surrounding Pivot 1, at Kleinkopje Colliery (Vermeulen and Usher, 2005). 


\begin{tabular}{|l|c|c|c|c|c|c|c|}
\hline \multicolumn{7}{|c|}{ TABLE 1 } \\
\multicolumn{8}{|c|}{ Input salt concentration of irrigation water and leachate concentration simulated by SWB } \\
\hline $\begin{array}{l}\text { Salt } \\
\left(\mathbf{m g} \cdot \boldsymbol{\ell}^{-1}\right)\end{array}$ & $\mathbf{C a}$ & $\mathbf{M g}$ & $\mathbf{N a}$ & $\mathbf{K}$ & $\mathbf{C l}$ & $\mathbf{S O}_{\mathbf{4}}$ & TDS \\
\hline Irrigation water (measured) & 481 & 268 & 47 & 0 & 38 & 1921 & 2755 \\
\hline Average leachate concentration (SWB) & 470 & 1082 & 191 & 1 & 153 & 4233 & 6131 \\
\hline
\end{tabular}

The system is flexible and can be managed depending on the objectives that one wants to achieve, be it maximum crop production, water use, job creation, economic return or maximum gypsum precipitation and minimum salt leaching (Annandale et al., 2002).

The purpose of establishing several field trials in different regions was to assess the sustainability of irrigation with gypsiferous mine-water under different environmental conditions, as well as to validate the SWB model for different climates, soils, cropping systems and water and salt balances. A detailed description of soil properties, water qualities and cropping systems at each mine are given by Jovanovic et al. (2002).

As the impact of irrigation with gypsiferous water on crops and soils seems minimal and manageable, the focus of more recent investigations has turned to the impact on groundwater quality. Boreholes drilled at the different mines, either inside or in close proximity to the irrigated fields, have shown very little salt moving through the soil profile in the short term ( 2 to 8 years). However, there are justifiable concerns by regulating authorities that this practice, especially if allowed on a large scale, will merely be 'buying time', and could in fact turn a point-source pollution problem into a more difficult to manage non-point source pollution problem. It is essential, therefore, to predict what the likely impact of large-scale irrigation could be on groundwater resources.

The South African National Water Act (No. 36 of 1998) classifies irrigation, including irrigation with excess mine-water, as a controlled activity that can only be practiced under licence. A current concern in the water-scarce Olifants River Catchment is that if all excess mine-water is used for irrigation in future, then the basic ecological and domestic needs of downstream water users may not be met. It is likely that a compromise will need to be agreed on between all stakeholders that provides for these basic needs, but also allows for irrigation with mine-waters as a cost-effective way of providing food security and employment in the future, as the region diversifies its economy away from coal mining.

\section{Field water balance}

It is, of course, impossible to measure long-term behaviour of a non-existing but proposed large-scale irrigation scheme. Models were therefore used to predict long-term environmental effects by simulating 30 years of irrigation with gypsiferous mine-water. The long-term effect of irrigation with gypsiferous mine-water on the soil was predicted with SWB (Annandale et al., 1999b). This is a daily time step, generic crop, irrigation scheduling model, simulating the soil-water and salt balance, as well as water stress- and soil salinity-affected crop growth. Water movement in the soil profile is simulated with a simple cascading model (Campbell and Diaz, 1988). Salt redistribution assumes complete mixing of irrigation and rainfall with the soil solution of the top soil layer, and similarly for the soil solution percolating to the next lower soil layer and so on. Precipitation and dissolution of gypsum and calcite are determined using the approach of Robbins (1991). Potential evapotranspiration is calculated adopting the internationally standardised FAO (Food and Agriculture Organisation of the United Nations, Rome, Italy) Penman-Monteith methodology (Allen et al., 1998). Long-term weather records for the simulations with SWB were generated using the CLIMGEN weather data generator of G.S. Campbell (Washington State University), which is a modified version of WGEN (Richardson and Wright, 1984). CLIMGEN has been assessed for South African conditions by Clemence (1997), who showed the estimates to be quite satisfactory.

Long-term simulations were carried out for a lucerne (Medicago sativa cv. Pan 4860) - fescue (Festuca arundinacea cv. A.U. Triumph) perennial pasture, on a loamy sand Bainsvlei soil (Soil Classification Working Group, 1991) or plinthic ferralsol (FAO, 1998). Water qualities typical for Kleinkopje Colliery were used as input (Table 1). Generated weather data for Ogies (lat. 26.13 $\mathrm{S}$; long. $28.72^{\circ} \mathrm{E}$; alt. $1571 \mathrm{~m}$, avg. rainfall $738 \mathrm{~mm}$ ), which is reasonably representative of climatic conditions in the Mpumalanga coalfields, were also used (Annandale et al., 1999b). Irrigations with gypsum-rich water (Table 1) were simulated to refill the soil profile on days when the calculated soil-water deficit was $>20 \mathrm{~mm}$ (Annandale et al., 1999a). Simulated average annual irrigation was $1141 \mathrm{~mm}$, with $279 \mathrm{~mm}$ the average annual drainage. Simulations showed that roughly half the added salts would be leached under these circumstances, which reflects a potential groundwater salt load reduction of $46 \%$ through gypsum precipitation. The simulated leachate qualities presented in Table 1 were used as inputs to the groundwater model.

\section{Modelling groundwater impact of large-scale irrigation in the Mpumalanga coalfields}

The localised impact of mine-water irrigation has been monitored for periods in excess of eight years. The results to date indicate a limited impact over this time, based on detailed regular groundwater monitoring (Vermeulen and Usher, 2005) as shown in Fig. 1. This monitoring is on a localised scale and cannot be used to unequivocally determine larger-scale irrigation impacts. Numerical groundwater models are, however, extremely useful tools to evaluate different scenarios of groundwater and solute movement (Spitz and Moreno, 1996).

\section{Model description}

The model for simulating the transport of groundwater and solutes (salts and other pollutants) is based on the finite element method as described by Pinder and Gray (1977). A dynamic numerical model for the area under investigation was constructed using the modelling package FEFLOW (Diersch, 1988). The first step in constructing such a model is the subdivision of the area to be modelled into elements where the characteristics are similar. Subdivision of an area is typically influenced by the surface geometry, such as topography and streams. The hydraulic characteristics of the underlying aquifer and the current groundwater quality distribution are also considered in each subdivision. The use of numerical groundwater models in the coalfields has proved to be useful in terms of 
evaluation of site-specific groundwater migration, regional impacts and management options (Grobbelaar et al., 2004; Usher et al., 2003). Prediction of water movement across an area in question requires solution of several sets of equations. The governing equations for numerical groundwater models are well described by authors such as Bear and Verruijt (1987). These describe the interpolation of groundwater levels using Bayesian interpolation, and the solution of the groundwater flow equation (a second order partial differential equation) across the whole area. The equations may be solved analytically for simple problems, but for more complex systems like the one analysed in this study, piece-wise approximations are obtained through the finite element method. Once the waterlevel distribution is available over the whole area, seepage velocities and directions are calculated and the response of the aquifer to external influences such as pumpage and recharge from irrigation and rainfall can be determined.

On the basis of the hydraulic gradients and flow velocities, movement of solutes through the aquifer may then be calculated using mass transport equations. It is clear from the above, that coupling of the mass transport equation with the flow equation becomes rather complex under real field conditions, because of the additional variables present and non-linearity in the equations. The dispersive properties of the soil and aquifer, degree of advection in the system, and the chemical reactions that take place, must all be identified before the mass transport equation can be applied successfully.

Certain simplifying assumptions may be made with respect to a specific simulation without jeopardising the value of the model. An example of this is that the vertical dimension in the equations may be eliminated, as most of the flow takes place within the weathered upper 10 to $15 \mathrm{~m}$. Laterally, the aquifer extends over several kilometres, up to the nearest streams and beyond. The vertical dimension is therefore very small in comparison to the lateral dimensions. The time taken for the solute to travel vertically into the aquifer is therefore negligibly small in comparison to that needed for the solute to disperse regionally. Elimination of the vertical dimension, therefore, has little effect on estimated arrival time for the solute at some distant point relative to its source. Elimination of the vertical dimension from the simulation, however, considerably reduces complexity and computational effort. Another acceptable assumption for modelling purposes is that chemical constituents may be grouped into various categories, depending on their reactivity, attenuation and decay properties. For the simulation of the groundwater impact of large-scale irrigation with gypsiferous water, only conservative mass transport can be considered to obtain an indication of the extent of plume migration. Several retardation mechanisms may play a role to reduce the rate at which certain solutes migrate, but as an initial indication of migration, these can be disregarded.

Variables and constraints that affect the movement of solutes through an aquifer are typically:

- The transmissivity and hydraulic conductivity of the underlying strata.

- The storativity and effective porosity of the underlying strata.

- The hydraulic gradient, dispersion and convection characteristics of the aquifer.

- Boundaries such as dolerite dykes, catchment and surface.

- Other sources of water in the area such as streams, pans, dams and lakes.

- Sinks within the area where groundwater is abstracted or naturally emanates in the form of streams or fountains.

\section{Characteristics of the Mpumalanga Coalfied aquifers}

Three distinct superimposed groundwater systems are present in the Mpumalanga coalfields. They are the upper weathered Ecca aquifer, the fractured aquifers within the unweathered Ecca sediments, and the lower aquifer below the Ecca sediments.

\section{Upper weathered aquifer}

The Ecca sediments are weathered to depths of between 5 and $12 \mathrm{~m}$ below the surface throughout the area. The upper aquifer is associated with this weathered zone and water is often found within a few metres below surface. This aquifer is recharged by rainfall. The percentage recharge to this aquifer is estimated to be in the order of 1 to $3 \%$ of the annual rainfall, based on work in other parts of the country by Kirchner et al., (1991) and Bredenkamp (1978).

Observed flow in the catchment confirmed isolated occurrences of recharge values as high as $15 \%$ of the annual rainfall (Hodgson and Krantz, 1998). It should, however, be emphasised that in a weathered system, such as the Ecca sediments, highly variable recharge values can be found from one area to the next. This is attributed to the localised impact of mining and the composition of the weathered sediments, which range from coarsegrained sand to fine clay.

The aquifer within the weathered zone is generally lowyielding (range 100 to $2000 \ell \cdot h^{-1}$ ), because of its insignificant thickness. The good quality of this groundwater can be attributed to the many years of dynamic groundwater flow through the weathered sediments. Leachable salts in this zone have been washed from the system and it is only the slow decomposition of clay particles, which presently releases some salt into the water (Hodgson and Krantz, 1998).

\section{Fractured Ecca aquifer}

The fractured Ecca aquifers are comprised of un-weathered Ecca sandstones and shales, where fractures are the principal controls on groundwater movement. The pores within the Ecca sediments are too well-cemented to allow any significant flow of water. All groundwater movement therefore occurs along secondary structures, such as fractures and joints in the sediments. These structures are better developed in competent rocks, such as sandstone, hence the better water-yielding properties of these rocks. At depths below $30 \mathrm{~m}$, water-bearing fractures with significant yields were observed to be spaced at $100 \mathrm{~m}$ or greater distances (Hodgson and Krantz, 1998). Of all the un-weathered sediments in the Ecca, the coal seams often have the highest hydraulic conductivity.

\section{Lower aquifer}

Below the Ecca sediments, the Dwyka tillites have very poor aquifer properties. These aquifers need not be included in the modelling of the impact of mine-water irrigation, as the weathered and fractured aquifer will mainly transport any salt emanating from irrigation activities.

\section{Scenario simulation}

To evaluate the utilisation of larger-scale irrigation for postclosure mine-water management, the sub-areas west of Witbank where water will decant from the collieries has been considered. 
By way of demonstrating the potential impact that irrigating with such a large volume of water would have on the geohydrology of the area, 16 pivots of 40 ha each (Fig. 2) were accommodated in the finite element model for the area. The groundwater input quality and flux from each pivot are based on the results from the SWB simulation provided earlier in this paper. For this scenario, the pivots were placed in an area where the mining effects on soils and aquifers were expected to be minimal and in close proximity to the expected discharge area for the mine-water after closure. This would be convenient for the supply of water to the pivots, but as discussed later, might not be the optimal location from a groundwater hydrology perspective.

The transmissivity and hydraulic conductivity of the underlying strata will influence the movement of solutes. While no pumping tests have been performed at these hypothetical pivot sites, borehole logs indicate low-yielding characteristics for the aquifer. Records show that the average blow yield is in the order of $0.5 \ell \cdot \mathrm{s}^{-1}$, which translates into a hydraulic conductivity of 0.01 to $0.2 \mathrm{~m} \cdot \mathrm{d}^{-1}$, with an average value of $0.1 \mathrm{~m} \cdot \mathrm{d}^{-1}$.

The movement of solutes will also be influenced by the storativity and effective porosity of the underlying strata. The storage coefficient of aquifers in the Witbank/Highveld coalfields has been determined using pumping test methods, and an average value of $10^{-3}$ can be assumed for the fractured aquifer. The reason for this relatively low storativity value lies in the fact that only a small proportion of the pores and fractures in this aquifer partake in water flow. In the upper, weathered aquifer, the effective porosity is two orders of magnitude higher than the fractured aquifer, and a value of $10^{-1}$ can be assumed. This higher value is due to the fact that almost all the calcite that normally binds the sedimentary grains together has been leached from this horizon. Water can therefore permeate more easily through the weathered matrix.

As the regional water-table gradient and the dispersion and convection characteristics of the aquifer will also directly influence the movement of solutes, measurement of static water levels in the monitoring boreholes is necessary for the determination of the regional water-table gradient. Since the regional water-table gradient within the area is controlled by the surface topography, the latter may be used as a controlling factor in a Bayesian estimation model to infer groundwater levels in areas where monitoring boreholes are not available.

Groundwater boundaries exist in various forms in nature and have to be accounted for in models. Typical boundaries are dolerite dykes

Figure 2 (top right)

Pivot arrangement, surface contours and surface water bodies for the area modelled

Figure 3 (bottom right)

Simulated groundwater sulphate concentrations in $m g \cdot \ell^{-1}$
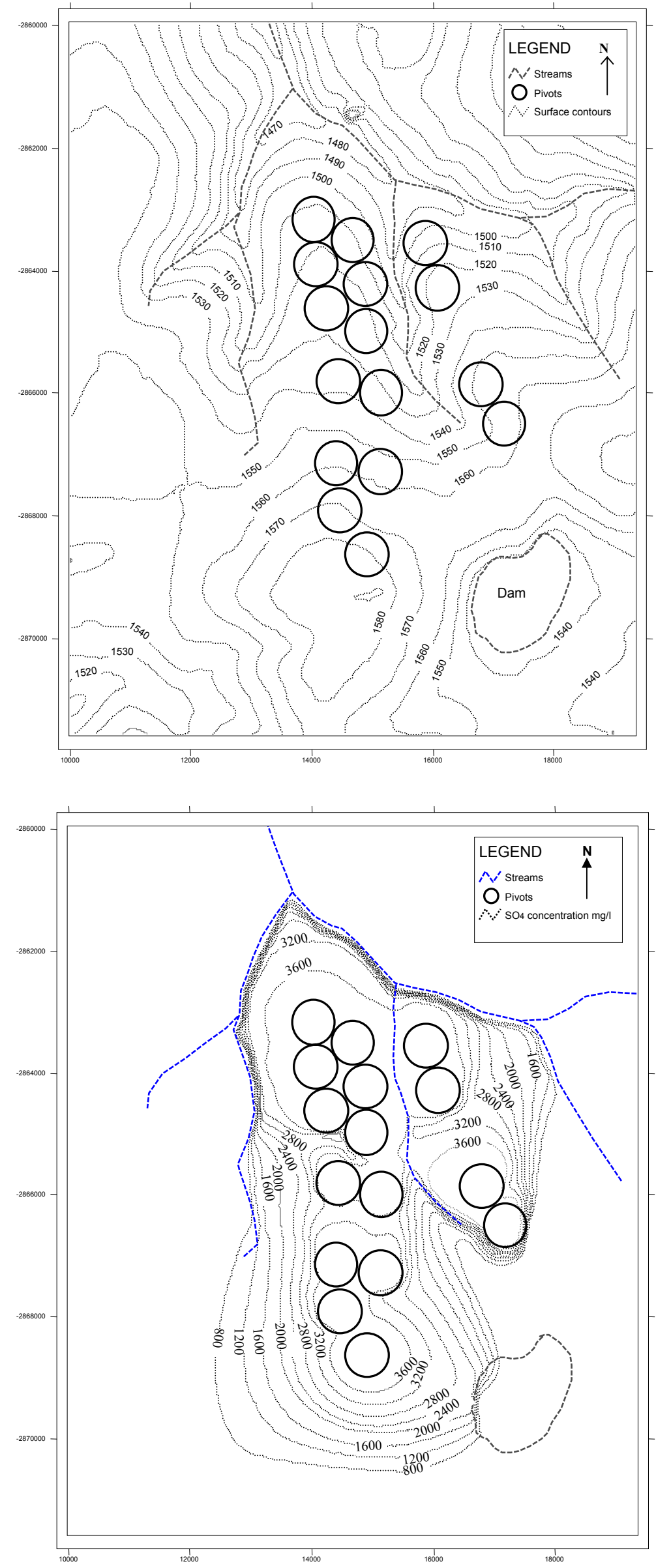
and sills, which may act as impermeable barriers in the transverse direction or as conductive zones along intrusive contacts. Close to the surface, dolerite weathers and groundwater readily permeates through it. Other boundaries are, for instance, catchment boundaries, where a change in the direction of the water-table gradient may occur. Surface boundaries, above which the groundwater level cannot rise without decanting, should also be considered. Boundaries of these types can be accommodated in flow and mass transport models, with the prerequisite that knowledge about these boundaries must be available for the area in question.

Taking all this into account, input data used in these particular simulations are summarised as follows:

$\begin{array}{lr}\text { Quality of deep drainage } & 6000 \mathrm{mg} \cdot \ell^{-1} \mathrm{TDS} ; 4000 \mathrm{mg} \cdot \ell^{-1} \mathrm{SO} \\ \text { Attenuation } & \mathrm{zer} \\ \text { Aquifer transmissivity } & 10 \mathrm{~m}^{2} \cdot \mathrm{d}^{-} \\ \text {Storage coefficient for the weathered strata } & 0.20 \\ \text { Recharge from rainfall (outside irrigated area) } & 3 \% \\ \text { Annual rainfall } & 740 \mathrm{~mm}\end{array}$

The steady state groundwater flow solution was used as basis for the mass transport simulations. This therefore represents the expected average groundwater plume development under natural conditions, without taking into account influences such as abstraction or temporal changes such as floods. For consideration of such aspects further specific scenarios should be simulated.

The steady state groundwater flow and superimposed mass transport solution represents the expected post-mine closure geohydrological situation and the mass transport under these conditions provides an indication of un-retarded salt migration. Surface contours, and the position of the pivots relative to the stream to the north and other boundary influences, are shown in Fig. 2, and the simulated steady state sulphate plume for the specific pivot arrangement is presented in Fig. 3. Units on the $\mathrm{X}$ and $\mathrm{Y}$ axes of these maps are in metres.

As shown in Fig. 3, groundwater and associated salts, fed by recharge from the pivots, will migrate towards the streams. Salts from the pivots should mainly migrate along the weathered zone. In instances where seepage from irrigation passes into deeper layers, this would flow back into the underlying collieries. The data in Fig. 3 for sulphate, demonstrate a flow scenario without retardation. Simulations show that groundwater will be intercepted at a rate of just over $2 \mathrm{M} \ell \cdot \mathrm{d}^{-1}$ by the streams. In other areas, salt accumulation in the groundwater will be regulated by dilution from rainfall.

It is important to note that $2 \mathrm{M} \ell \cdot \mathrm{d}^{-1}$ is the maximum volume of deep drainage water that could flow through this specific aquifer for the indicated pivot configuration. The SWB simulations, however, showed that the deep drainage from the irrigation pivots may be in the order of $4.9 \mathrm{M} \ell \cdot \mathrm{d}^{-1}$. This would result in areas becoming waterlogged and the irrigation scheme would fail in the long term.

While this paints a picture that suggests that mine-water irrigation is not practicable in the longer term, several potential solutions are possible. The first potential solution to this problem would be to rearrange the pivots in a longer N-S transect, if suitable soils were available. This would increase the area to the east and west through which the excess recharge could be transmitted to the streams. Another solution would be to reduce the recharge emanating from the fields by increasing the irrigated area and reducing the irrigation application on an aerial basis.
Perhaps the most promising solution lies in the application of the excess water to rehabilitated opencast spoils. These areas have already been impacted by mining and the salts leached from irrigation can be regarded as being fed into the same system from which they originate. Grobbelaar et al. (2004) report that there are at least 38000 ha of reclaimed open-cast mine-land in the Witbank/Highveld coalfields, with this area growing as mining and rehabilitation continue. The benefits of not exporting salts to unimpacted areas and of utilising this vast area of land provide a great opportunity for mine-water irrigation.

Irrigation of reclaimed land may require piping water to these areas, which are slightly further away than the modelled area described above. Water-logging is, however, not likely to be as problematic if the spoils have been rehabilitated in such a way as to allow free drainage from the bottom of the root zone, since the spoil material itself behaves as a highly transmissive unconsolidated porous medium. Mine spoils exhibit average hydraulic conductivities two orders of magnitude greater (geometric mean) than adjacent un-mined strata (Hawkins, 1998), provided that hardpans do not form or that weathering results in a decrease in permeability in the upper layers of the spoil. Dense layers have been found in spoils in South Africa, but it has been found in older spoils in South African coalfields that these layers appear to become less prevalent over time, and that coarse fragments in the upper soil appear to weather rather rapidly (Viljoen, 1992). Nonetheless, it may be necessary in some places to enhance drainage by agricultural practices that relieve compaction, or even through the installation of efficient but expensive artificial drainage. Under non-irrigated conditions it has been found that the recharge capacity of the spoils is five to six times (in the order of 15 to $20 \%$ of MAP) greater than that occurring in the weathered Ecca not impacted by mining (recharge of around 3\%), (Hodgson and Krantz, 1998; Van Tonder et al., 2003).

First indications from the modelling exercise are that such an irrigation configuration could be viable because of the limited aerial extent of the sulphate plume and the interception of the plume that is possible in the streams. As part of an overall mine-water management strategy, irrigation therefore appears to hold significant promise.

\section{Conclusions}

Results of this study suggest that irrigating large areas with gypsum-rich wastewater could be feasible and sustainable if careful attention is paid to the specificity of each situation. It is also clear, however, that large errors can be made in designing such irrigation schemes if the amount of deep drainage leaving the root zone, the storage capacity between the base of the root zone and the underlying aquifer systems, and the hydraulic characteristics of the aquifers are not properly matched. Percolation from irrigation in excess of what the underlying aquifers can transmit from the site will lead to rising water tables, and over time, water-logging and salinisation of the root zone. This will necessitate the installation of expensive drainage systems, or ultimately, result in the failure of the irrigation scheme. In order to improve on the analyses and results presented in this paper, it is essential that soil-water balance and groundwater models are coupled in a way that includes the feedback needed between them to more accurately describe the system to be managed. This will ensure that irrigation with gypsiferous mine-water can be seriously considered as part of the solution towards the challenge of responsible management of the considerable volumes of mine-water available during 
mining operations and post-closure. The importance of proper site characterisation for the successful application of minewater irrigation is also evident.

\section{Acknowledgements}

The authors gratefully acknowledge the financial, technical and moral support of the Water Research Commission through Mr Meiring du Plessis (Research Manager) and the coal-mining industry through Coaltech 2020. The co-operation of Kleinkopje, New Vaal, Optimum and Syferfontein Collieries is also acknowledged. The project was also supported financially by the Department of Trade and Industry through the THRIP programme, and was ably managed by Mr Johann Beukes (Project Manager) of Coaltech 2020.

\section{References}

ALLEN RG, PEREIRA LS, RAES D and SMITH M (1998) Crop Evapotranspiration. Guidelines for Computing Crop Water Requirements. FAO Irrigation and Drainage Paper No. 56. FAO, Rome, Italy.

ANNANDALE JG, BENADÉ N, JOVANOVIC NZ, STEYN JM and DU SAUTOY N (1999a) Facilitating Irrigation Scheduling by Means of the Soil-Water Balance Model. WRC Report No 753/1/99, Water Research Commission, Pretoria, South Africa.

ANNANDALE JG, JOVANOVIC NZ, BENADÉ N and TANNER PD (1999b) Modelling the long-term effect of irrigation with gypsiferous water on soil and water resources. Agric. Ecosyst. Environ. 76 (109-119).

ANNANDALE JG, JOVANOVIC NZ, CLAASSENS AS, BENADÉ N, LORENTZ SA, JOHNSTON MA, TANNER PD, AKEN ME and HODGSON FDI (2001) The Influence of Irrigation with Gypsiferous Mine-water on Soil Properties and Drainage Water. WRC Report No K5/858, Water Research Commission, Pretoria, South Africa.

ANNANDALE JG, JOVANOVIC NZ, TANNER PD, BENADÉ N and DU PLESSIS HM (2002) The sustainability of irrigation with gypsiferous mine-water and implications for the mining industry in South Africa. Mine-Water Environ. 21 (81-90).

BARNARD RO, RETHMAN NFG, ANNANDALE J, MENTZ WH and JOVANOVIC NZ (1998) The Screening of Crop, Pasture and Wetland Species for Tolerance of Polluted Water Originating in Coal Mines. WRC Report No 582/1/98, Water Research Commission, Pretoria, South Africa.

BEAR J and VERRUIJT A (1987) Modelling Groundwater Flow and Pollution. D. Reidel Publishing Company. $414 \mathrm{pp}$.

BELETSE YG (2004) Modelling the Soil-Water and Salt Balance of Planted Pastures Irrigated with Sodium Sulphate Rich Mine Effluent. M.Sc. Dissertation. Dept of Plant Production \& Soil Science, University of Pretoria.

BREDENKAMP DB (1978) Quantitative Estimation of Groundwater Recharge With Special Reference to the Use of Natural RadioActive Isotopes and Hydrological Simulation. Ph.D. Thesis, UOFS, Bloemfontein. 367 pp.

CAMPBELL GS and DIAZ R (1988) Simplified soil-water balance models to predict crop transpiration. In: Bidinger FR and Johansen C (eds.) Drought Research Priorities for the Dryland Tropics. ICRISAT, India. 15-26.

CLEMENCE BSE (1997) A brief assessment of a weather data generator (CLIMGEN) at South African sites. Water SA 23 271-274.

DIERSCH HG (1988) FEFLOW Reference Manual. Institute for Water Resources Planning and System Research Ltd., Walterdorfer Str 105 , D-12526, Berlin.

DU PLESSIS HM (1983) Using lime treated acid mine-water for irrigation. Water Sci. Technol. 151 (45-154).

FAO (1998) World Reference Base for Soil Resources. World Soil Resources Report No. 84, Food and Agriculture Organization of the United Nations, Rome, Italy. 88 pp.
GROBBELAAR R, USHER B, CRUYWAGEN L-M, DE NECKER E and HODGSON FDI (2004) Long Term Impact of Intermine Flow from Collieries in the Mpumalanga Area. WRC Report No 1056/1/04, Water Research Commission, Pretoria.

HAWKINS JW (1998) Hydrogeologic Characteristics of Surface Mine Spoil in Coal Mine Drainage Prediction and Pollution Prevention in Pennsylvania, the Pennsylvania Department of Environmental Protection. Report No 5600-bk-dep2256.

HODGSON FDI and KRANTZ RM (1998) Groundwater Quality Deterioration in the Olifants River Catchment above the Loskop Dam with Specialised Investigations in the Witbank Dam Sub-Catchment. WRC Report No 291/1/98, Water Research Commission, Pretoria.

JOVANOVIC NZ, BARNARD RO, RETHMAN NFG and ANNANDALE JG (1998) Crops can be irrigated with lime-treated acid mine drainage. Water SA 24 113-122.

JOVANOVIC NZ, ANNANDALE JG, VAN DER WESTHUIZEN AM and STEYN JM (2002) Monitoring the soil-water and salt balance under irrigation with gypsiferous mine wastewater. Surface Mining 2002 - Modern Development for the New Millennium. ISBN 1-919783-40-7, South African Institute of Mining and Metallurgy.

KIRCHNER J, VAN TONDER GJ and LUKAS E (1991) Exploitation Potential of Karoo Aquifers. WRC Report No 170/1/91, Water Research Commission, Pretoria, South Africa.

OSTER JD and RHOADES JD (1975) Calculated drainage water composition and salt burdens resulting from irrigation with river waters in the Western United States J. Environ. Qual. 4 (73-79).

PINDER GF and GRAY WG (1977) Finite Element Simulation in Surface and Subsurface Hydrology. Academic Press, London. ISBN 0-12-556950-5

PULLES W, HOWIE D, OTTO D and EASTON J (1995) A Manual on Mine-water Treatment and Management in South Africa. WRC Report No TT 80/96, Water Research Commission, Pretoria, South Africa.

PULLES W, HEATH R and HOWARD M (1996) A Manual to Assess and Manage the Impact of Gold Mining Operations on the Surface Water Environment. WRC Report No TT 79/96, Water Research Commission, Pretoria, South Africa.

RICHARDSON CW and WRIGHT DA (1984) WGEN: A Model for Generating Daily Weather Variables. US Dept. of Agriculture, Agricultural Research Services. $83 \mathrm{pp}$.

ROBBINS CH (1991) Solute transport and reactions in salt-affected soils. In: Hanks RJ, Ritchie JT (eds.) Modelling Plant and Soil Systems. Agronomy Monograph No. 31, ASA-CSSA-SSSA, Madison, Wisconsin, USA. 365-395.

SOIL CLASSIFICATION WORKING GROUP (1991) Soil Classification. A Taxonomic System for South Africa. Dept. of Agricultural Development, Pretoria, South Africa. 262 pp.

SPITZ K and MORENO J (1996) A Practical Guide to Groundwater and Solute Transport Modelling. John Wiley \& Sons, Inc. New York.

TANNER PD, ANNANDALE JG and RETHMAN NFG (1999) Converting problems into opportunities - The use of gypsiferous minewater for crop irrigation. Proc. $22^{\text {nd }}$ Conf. Soil Science Soc. of South Africa. Pretoria, South Africa. 160-162.

THOMPSON JG (1980) Acid mine-waters in South Africa and their amelioration. Water SA 6 130-134.

USHER BH, HAVENGA A, HOUGH J, GROBBELAAR R and HODGSON FDI (2003) The challenges of determining intermine flow in the Witbank Coalfield of South Africa. Proc. Water in Mining 2003: The Role of Water in a Sustainable Minerals Industry. 13-15 October 2003, Brisbane, Australia. The Australian Institute of Mining and Metallurgy, Carlton, Australia.

VAN STADEN CM (1979) How ERPM uses lime to solve unique underground water problem. Coal, Gold and Base Minerals of South. Afr. 27 (5) 100-109.

VAN TONDER G, VERMEULEN D, COGHO V and KLEYNHANS J (2003) Prediction of the decant rate and sulphate concentration from rehabilitated open cast coalmines in South Africa. Proc. $6^{\text {th }}$ ICARD, Cairns, Queensland. 12-18 July 2003.

VERMEULEN PD and USHER BH (2005) Determination of the impact of mine water irrigation on groundwater resources. Proc. Securing 
the Future, 2005 - Int. Conf. Mining and the Environment, Metals and Recovery. June 27-July1 2005. Skelleftea, Sweden. ISBN 91975190-1-4.
VILJOEN JNJ (1992) Soil development in rehabilitated coal mine spoil: preliminary observations. Proc. $17^{\text {th }}$ Congress, Soil Sci. Soc. S. Afr. 28-30 January 1992, Stellenbosch, South Africa. 